\title{
原著
}

\section{経鼻的持続陽圧呼吸療法が失語症の機能回復に寄与した 閉塞型睡眠時無呼吸低呼吸症候群の一例}

\author{
伊 藤 永 喜 * 佐 野 洋子** 小嶋 知 幸 ${ }^{* *}$ \\ 新 海 泰 久*** 加 藤 正 弘***
}

要旨：閉塞型睡眠時無呼吸低呼吸症候群（obstructive sleep apnea hypopnea syndrome：以下, OSAHS）に対する治療目的に導入した経鼻的持続陽圧換気療法 (nasal continuous positive airway pressure : 以下, nCPAP) が，言語機能回復に奏効したと考えられる失語症例を経験した。症例は 43 歳, 右利き男性。脳静脈洞血栓症に対するシャント手術後に脳内出血を発症, 右半身の不全麻痺 と重度失語症が残存。発症 8 力月後に江戸川病院にて, 本格的な言語訓練開始となる。病前より夜 間無呼吸・いびきがあり, 終夜睡眠ポリグラフィ（PSG）の結果, 中等度閉塞型睡眠時無呼吸低呼 吸症候群と診断された。失語症に対する言語訓練が開始されてから約 2 年経過した時点より nCPAP を開始したところ, 失語症状の中でも回復に困難を示していた標準失語症検査での発話の項目など で検査上顕著な改善を認めた。また日常の発話においても流暢性が増して意思疎通性が大幅に改善 した。以上より, nCPAP 治療が OSAHS を合併する失語症者の言語機能回復に奏効する可能性が示 唆された。

(高次脳機能研究 25 (2) ：187 194，2005）

Key Words : 閉塞型睡眠時無呼吸低呼吸症候群, 失語症, 脳血管疾患, 経鼻的持続陽圧換気療法, 言語療法 obstructive sleep apnea hypopnea syndrome (OSAHS), aphasia, cerebrovascular disease, nasal continuous positive airway pressure (nCPAP), speech therapy

\section{はじめに}

閉塞型睡眠時無呼吸低呼吸症候群（OSAHS）は, 睡眠中に上気道の閉塞により呼吸の停止が反復し て生じる症状で，ときに大きないびきを伴う。脳 波では頻回に覚醒反応（arousal response）が認め られ，これにより睡眠の障害・分断があり，日中 の過眠をきたす。最近の欧米の疫学調査において 男性の $4 \%$, 女性の $2 \%$ 占めるとされ, けっし てまれな疾患ではない。とくに，虚血性心疾患患 者では約 $2 \sim 3$ 倍, 高血圧患者では約 2 倍, 脳血 管障害患者では約 3〜 5倍の割合で合併すること が知られており, 生活習慣病のリスクファクター としても重要である。

とくに，脳卒中や一過性脳虚血発作を発症した
患者の約 $70 \%$ OSAHS が合併し（Bassetti ら 1996, Dyken ら 1996), OSAHS 患者の直接死因の 多くが脳血管障害であったとする報告 （Koskenvuo ら 1985）があるほど，OSAHS患者に 合併した脳血管障害は予後を規定する重要な因子 である。また失語症は, 脳血管障害の後遺症とし て重大でありその回復は容易ではない。失語症の 回復メカニズムはいまだ解明されていないが，慢 性期の回復の予後には残存脳の状態の良否がかか わることが近年わかってきている。今回われわれ は, 脳血管障害に起因する失語症例に, 失語症発 症以前から罹患していたと思われるOSAHSの治 療を目的として経鼻的持続陽圧換気療法 (nasal continuous positive airway pressure : nCPAP ) を導 入したところ, 言語機能の短期間での著明な改善 
をみたので報告し, OSAHSの患者において nCPAPの施行が失語症の回復に良好な影響を与え る可能性について検討する。

\section{I. 症例}

\section{1. 症例の概要（初診時）}

症例：T. Y. 氏。43歳の右利き男性。身長： $162 \mathrm{~cm}$, 体重：58kg, BMI：22.1。大卒。製薬会 社の営業マンであった。既往歴：特記事項なし。

生活歴：喫煙はせず, 飲酒も少量。26歳ごろか ら妻に夜間のいびきと無呼吸を指摘されていたが 放置していた。

現病歴：1999年 3 月 A 病院で脳静脈洞血栓症・ 水頭症に対するシャント術施行に続発して, 左脳 内出血・脳浮腫を発症し, 開頭減圧手術 - 低体温 療法などを実施。その後約 2 力月は意識レベルも 不良で，ほほ全失語の状態であった。発症 8 力月 後に江戸川病院で失語症に対する集中的言語訓練 を開始した。

初診時所見（1999年 11月）：

(1) 神経学的所見 : 右不全麻痺, 右同名半盲を 認めた。ぎこちない動きではあるが独歩可能。

(2) 神経放射線学的検査では, MRI T 2 強調画像 で, 左側頭・頭頂葉の皮質・皮質下に広範な高信 号域を認め, また脳浮腫が寛解後に施行した頭蓋 骨形成術が確認された（図 1）。
（3）神経心理学的所見：重度流暢型失語症とと もに，観念運動失行，右視空間への不注意が認め られた。非言語的知的機能検査であるレーブン・ マトリシス検査は 37 点満点中 34 点と良好な成績 であるが，WAIS-R成人知能検査の動作性 IQ は 74 とやや低值であった。

失語症は重篤で表出・理解ともに重度に障害さ れていた。構音失行症状は認めず，その意味では 流暢型失語に分類される。しかし音韻を探しなが ら発話するため, 発話は著しく停滞した。単語の 復唱, 呼称, 音読のいずれもほぼ不能。また漢 字・仮名ともに書字は不能。意味理解は, 聴覚経 路, 視覚経路ともに単語レベルはおおむね可能で あったが，文章の理解は困難。標準失語症検査 （以下，SLTA）成績（図 2）に初診時の言語検査 結果を示す。

SLTAの呼称課題での発話例を示す。「冷蔵庫」 を「くす・たべる」。「ぶどう」を「み・る・じゃ ないと・み・うに・つう・つみ・みずみ」。「本棚」 を「ほ・ほ・たる・ん・こず・こん・こる・こ に・とる」「苜」を「み・えーと。これは・め・ す・す・す・すくる・す・い・ち・いち・ご・い ちご」。

漢字音読，仮名音読，復唱もいずれも同様の反 応であった。

2. OSAHS 治療開始前の言語訓練経過（1999

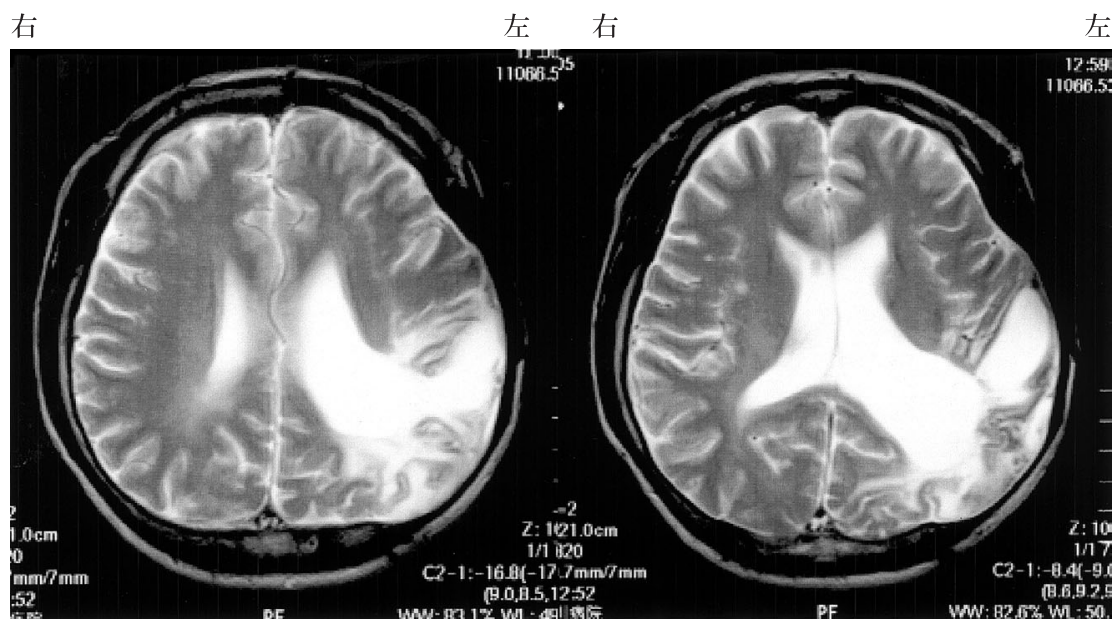

図1 T. Y. 氏 MRI T 2 強調画像所見 左側頭・頭頂葉の皮質・皮質下に広範な高信号域を認める。 


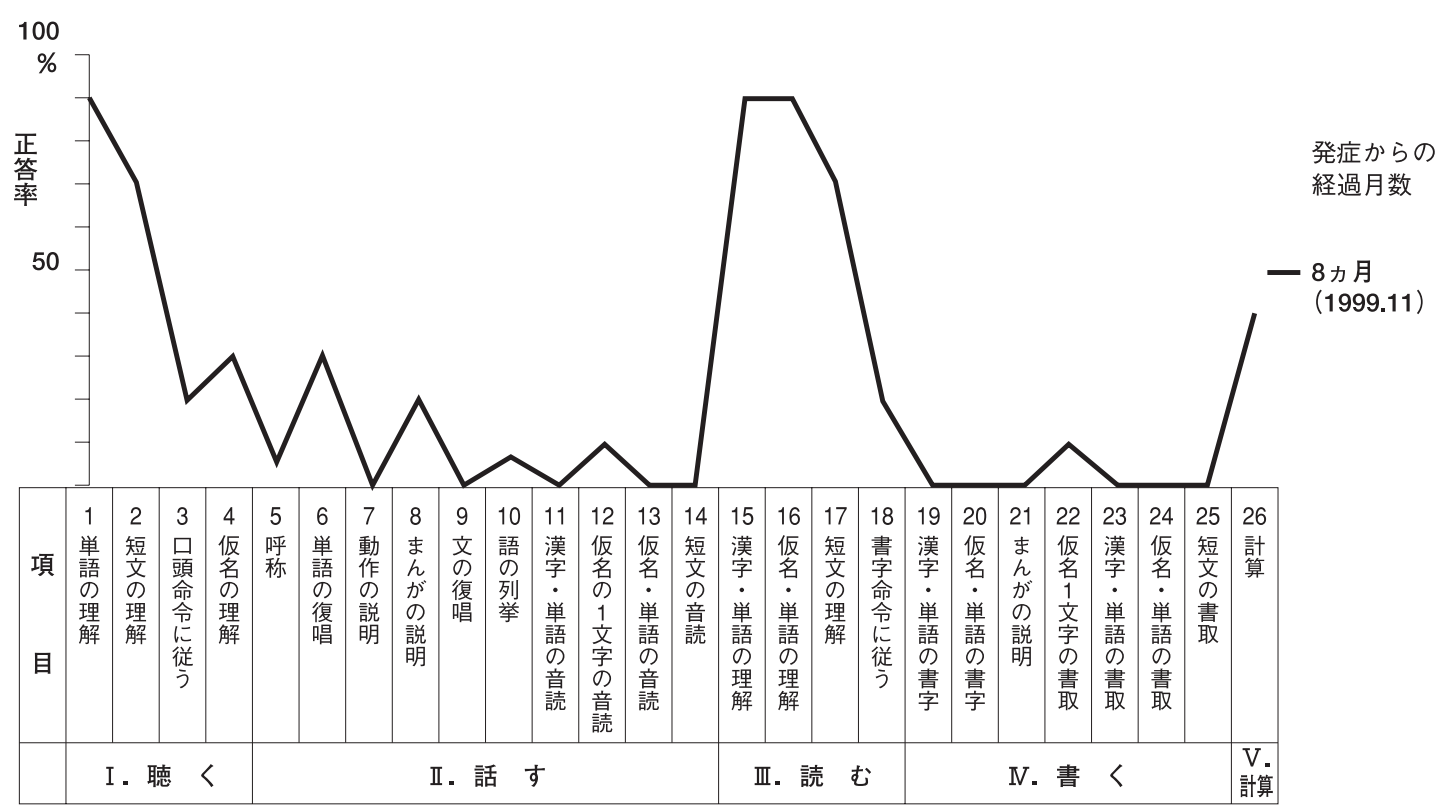

図2 T. Y. 氏 SLTA経過（初診時1999年11月）

\section{年 11 月～2001年 10 月)}

重篤な失語症である本症例に対して，5 月月間 は入院で毎日, その後は外来で週 4 回程度の頻度 で言語訓練を行った。その他毎日 $2 \sim 4$ 時間程度 かかる自習訓練課題が与えられた。

約 2 年に及ぶ集中的な言語訓練により，聴覚的 意味理解, 仮名文字の音読を中心にかなりの言語 機能の回復がみられた。しかしながら, 訓練開始 から 1 年 11 力月目の SLTA 検査結果（2001年 2 月 時点）と，その後 2 年 8 力月目の検査結果 (2001 年 11月時点）を比較すると（図 3), 意味理解 · 発話課題では改善はほとんど認められない。

とくに呼称や漢字音読課題では, 音韻を想起で きないため, 初診時と同様に音韻を探索し言いよ どむ症状は消えず，2001年 11月の SLTA 呼称課題 の正答率は 20 問中 4 問, 漢字単語音読も 5 問中 1 問にとどまっていた。

2001 年 11 月時の SLTA の呼称課題での反応を記 す。初診時にみられた意味不明な音韻の羅列は減 少したが，発話行動に移る前に口を動かしている 様子が観察され，脳内での音韻の探索を推察され る場面が多かった。たとえば「新聞」を「しん・ しん・あれ・せ・しん・しん・ぶ・ん・しんぶ
ん」,「金魚」を「えーと・か・これ・きん・き ん・ご・きんじょ・きん・きんご・きんしゃ・き んぎょ」,「とりい」を「これは・きゃ・にゅ・や」, 15 秒経って「と」の音韻のヒントを与えても， 「と・たちつてと・と・とは・とは・とけ・とわ」 と正答に至らない。

また意味理解の訓練も集中的に実施していたが, 「口頭命令」「書字命令」課題の正答率は $4 \sim 5$ 割 にとどまっていた。

\section{OSAHS 治療開始前後の経過（2001 年 9 月}

\section{～ 2002 年 5 月)}

(1) nCPAP 導入前後の OSAHS の症状

2001 年 9 月 5 日, OSAHS の精査治療目的に呼吸 器科受診となる。第 1 夜の終夜睡眠ポリグラフィ (polysomnography : 以下, PSG) の検査結果を示 す（表 1)。睡眠潜時は 12 分，睡眠効率は $79.8 \%$ であった。無呼吸低呼吸指数 (apnea hypopnea index : 以下, AHI) は $22.8 / \mathrm{hr}$, 覚醒指数 (arousal index) 36.1/hrであった。また, 総睡眠時 間に対する各睡眠段階は, stage 1 で 79 分, $20.5 \%$, stage 2 で 188.5 分， $48.8 \%$ ，深睡眠は睡 眠中の動脈血酸素飽和度 $\left(\mathrm{SpO}_{2}\right)$ の最低值は $78 \%$ で，約 6 時間 30 分の睡眠中約 15 分間 $(3.9 \%)$ は 


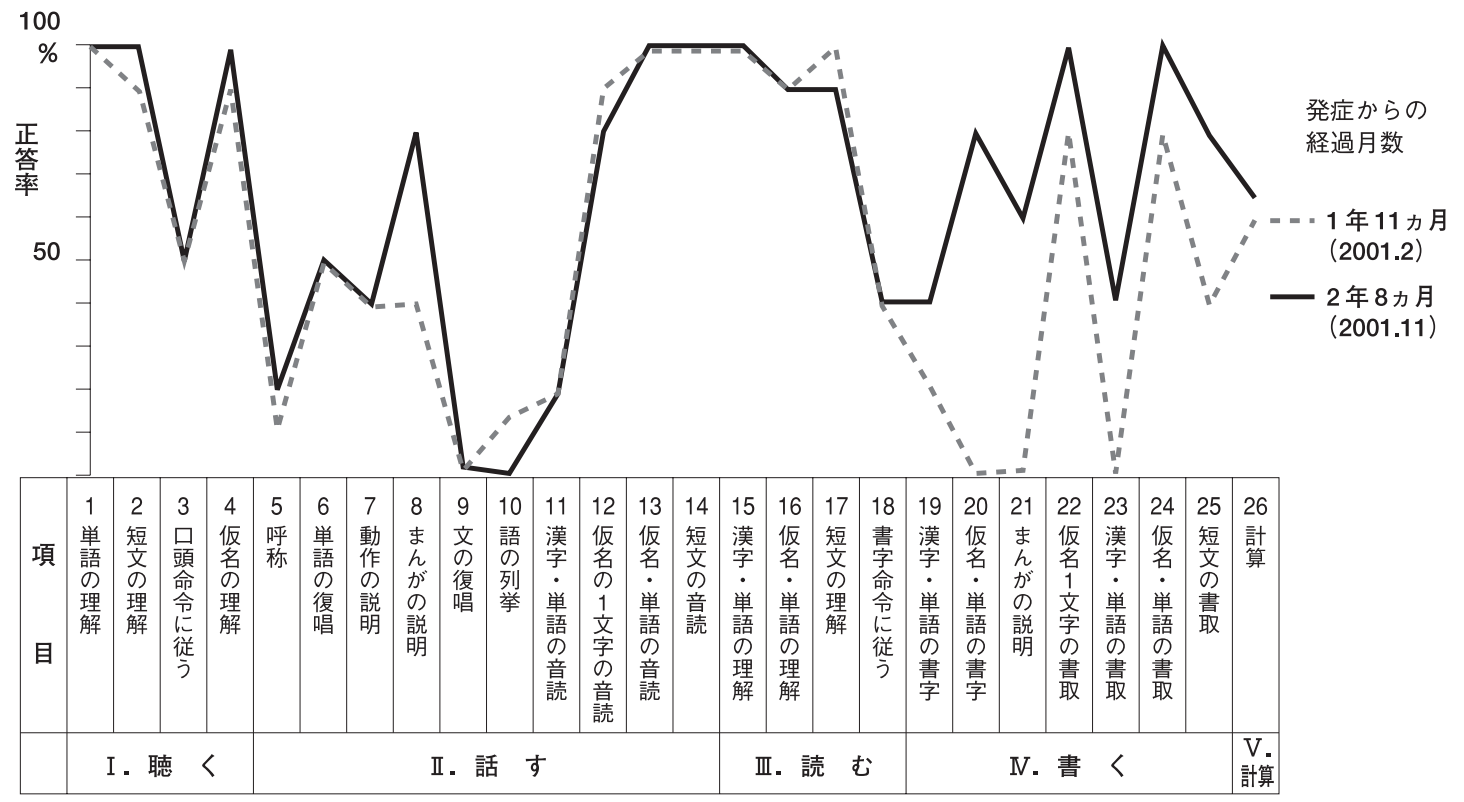

図3Ｔ. Y. 氏 SLTA経過（2000年7月～2001年11月）

表 1 nCPAP前後における睡眠構築の変化

\begin{tabular}{|c|c|c|c|}
\hline & & \multicolumn{2}{|c|}{ nCPAP Therapy } \\
\hline & & 前 & 後 \\
\hline 総睡眠時間 & $\min$ & 386.0 & 459.0 \\
\hline 睡眠潜時 & $\min$ & 12.0 & 8.0 \\
\hline 睡眠効率 & $\%$ & 79.8 & 93.2 \\
\hline Stage 1 & $\min (\%)$ & $79.0 \quad(20.5)$ & $123.5(27.4)$ \\
\hline Stage 2 & $\min (\%)$ & $188.5(48.8)$ & $171.0(38.0)$ \\
\hline Stage $3+4$ & $\min (\%)$ & $29.5(7.7)$ & $59.0(13.1)$ \\
\hline REM 睡眠 & $\min (\%)$ & $89.0 \quad(23.0)$ & $97.5(21.5)$ \\
\hline Total AHI & $/ \mathrm{hr}$ & 22.8 & 6.1 \\
\hline Arousal Index & $/ \mathrm{hr}$ & 36.1 & 13.7 \\
\hline Lowest $\mathrm{SpO}_{2}$ & $\%$ & 78 & 89 \\
\hline $\mathrm{SpO}_{2}<90 \%$ & $\min$ & 15.0 & $<0.1$ \\
\hline
\end{tabular}

$90 \%$ 未満であった。以上から中等度の OSAHS と 診断し, 翌日 nCPAP titration を施行し, 治療圧を $7.4 \mathrm{cmH}_{2} \mathrm{O}$ に設定した。 nCPAP 後の PSG 検査では, AHI 6.1/hr, arousal indexは 13.7/hr まで改善した。また深睡眠 59 分， $13.1 \%$ ，レム睡眠 97 分， $21.5 \%$ といずれも増加， stage 1 と 2 は相対的に減少し, 睡眠の質は改善を みた。また $\mathrm{SpO}_{2}$ の最低值は $89 \%$ となり，90\%未 
満はほんのわずかとなった。nCPAP 治療開始後は, 他覚的には夜間の無呼吸やいびきがほとんどなく なり, 自覚的には日中の眠気, 倦㤐感, 肩こりな どOSAHSによる症状がいずれも改善した。

ただしマスクの形状調整が繰り返し行われ，10 月 25 日まで安定した nCPAP施行はできなかった。

（2）失語症状の経過

2001 年 9 月から 2002 年初めにかけて, 外来言語 訓練での課題の内容や訓練量にとくに変わりはな かったが，年末から年始は多忙で，自習の量はむ しろ減少傾向にあった。しかしながら nCPAPが順 調に作動した 10 月末から 2 カ月たった 2002 年年 初に，「何だか話が少し楽にできるようになってき た」との訴えがあり, SLTAを 2002 年 2 月に施行 (図 4)。その結果，2001年の 11 月の時点まで低迷 していた「呼称」課題が，4 語から 10 語（20問中） に,「漢字単語の音読」課題は 1 語から 4 語（5問 中）へ，「書字命令に従う」（視覚的意味理解）課 題が 4 問から 6 問（10 問中），「漢字単語の書取」 課題が 2 問から 4 問（5問中）正答へと大幅に改善 がみられた。この検査成績上の変化は，明らかに 短期間での改善率の増加であり，それまでの緩や かな回復経過とは明らかに様相が異なるものであ
つた。

2002 年 2 月の SLTA 呼称課題では, ランダムに いろいろの音韻を言ってみて音韻を探索する反応 はきわめて少なくなり，また「流暢によく話す」 との印象がさらに濃厚になっていった。2002 年 5 月に実施したSLTA所見上は呼称課題が 20 問中 12 語正答とさらに改善し，また漢字単語の音読も 5 問全問正答に至った。一方, 聴覚的意味理解の $\lceil$ 口頭命令に従う」が 10 問中 6 問正答, 視覚的意 味理解の「書字命令に従う」が 9 問正答といずれ もさらに改善した。

このような発話および意味理解を中心とした失 語症の改善は, 心理的にもよい影響を与え， 2002 年 12 月の復職の期限を目指してさらに活動的な生 活を日々送るようになった。

この間特徵的な出来事としては，2002 年 6 月に 所用でnCPAPの器具を持たないまま 3 日間外泊し た折，短文の音読が著しくできなくなったことが あった。その折の訓練時の反応を示す。「正式に契 約を結ぶ」という文章の音読が，「せい・せい・さ い・せいじ・せいしゅ・せいしきに・む・み・ か・けいしき・けいけい・けいれ・けいら・けい しき・むけ・むけぶ・むる・むすぶ」。のレベル

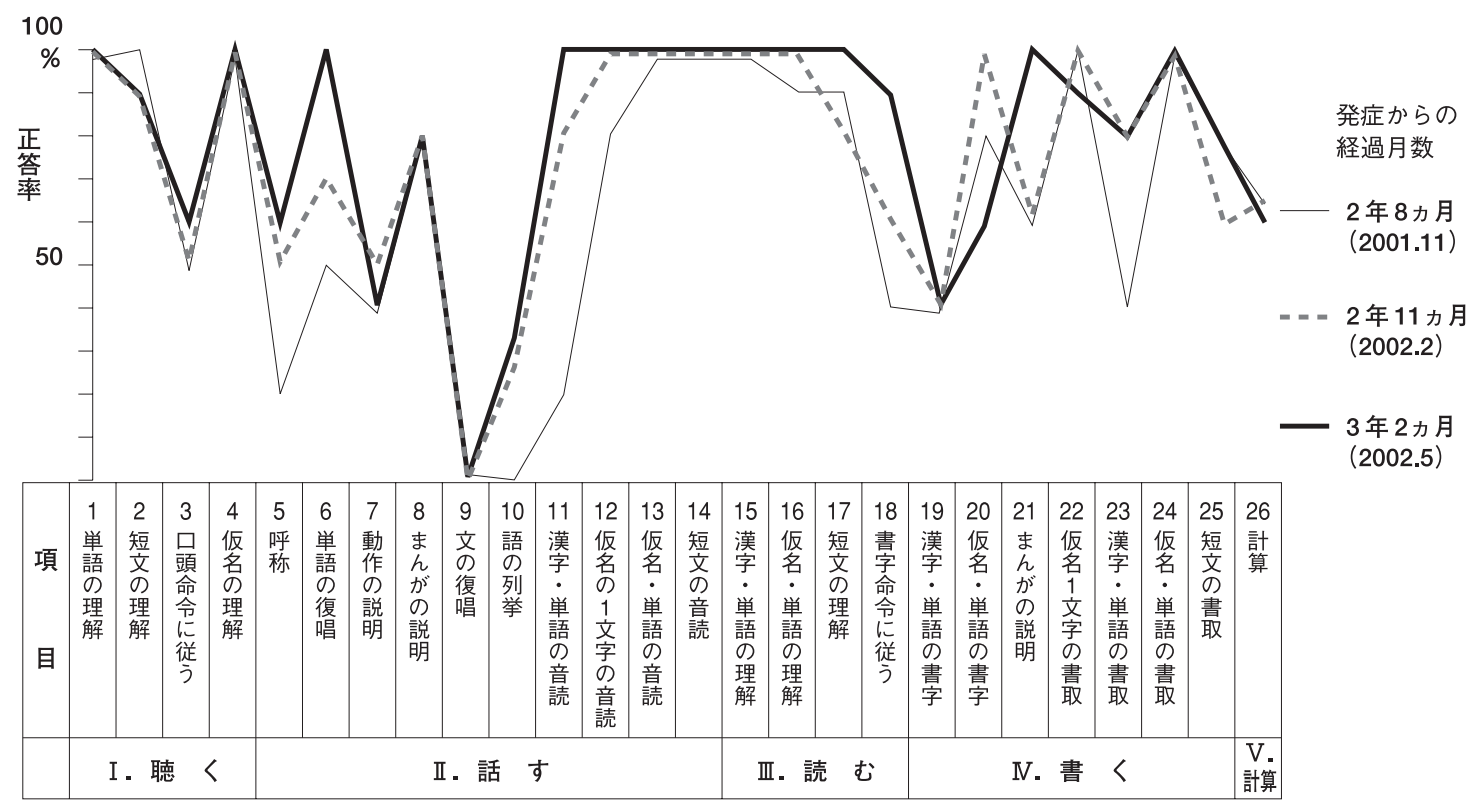

図4 T. Y. 氏 SLTA経過（2001年11月～2002年5月） 
の音読は比較的スムーズになっていたので，この 反応の低下に驚いて, 業者に依頼して器具を至急 貸し出してもらった。この文章を音読しにくい傾 向は 2 週間ぐらいとくに顕著であった。

なお WAIS-Rの非言語性の検査は，初診時に 74 であった動作性 IQ が, nCPAP 開始直後の 2001 年 12 月に 91 , 約 1 年後の 2002 年 12 月時に 100 と回 復傾向を示した。脳機能全体にも nCPAPの実施が よい影響を与えた可能性が示唆される。

\section{II. 考察}

今回, 閉塞型睡眠時無呼吸低呼吸症候群の合併 に対して導入したnCPAPが，言語症状の改善に大 きく寄与したと考えられた脳血管障害後の失語症 例を経験した。

本症例は脳血管障害発症以前からいびきと無呼 吸を家族から指摘されており, 睡眠センターなど への受診を検討していた矢先の発症であった。発 話を中心に回復不良なこの経過については，本症 例が比較的若年の発症である点, 十分な訓練をす でに 2 年近く実施している点, さらに後方限局損 傷の若年発症例の予後が一般には比較的よいこと （佐野ら 1992, 佐野ら 1996）などを鑑みると, 改 善経過が今ひとつ順調でないとの印象が否めなか った。

Partinen ら（1985）は，脳梗塞患者に発症以前 からのいびきの常習者が多いことを報告し，50人 の患者のうち 6 人に脳梗塞発症前に睡眠中の無呼 吸が存在していたと記載している。また， Koskenvuo ら（1987）は 0〜69歳の 4388 人の男 性を対象に 3 年間の全国規模の追跡調査を行い, その結果 1296 人のいびき常習者のうち 16 人に脳 血管障害が発症し，一方 480 人のいびきをかかな い群には 1 人も発症しなかったと報告している。 これらは，いびきと脳血管障害発症が強く関与す ることを示唆する報告であり，本症例において， 脳血管障害以前の睡眠検査データはないものの, その経過より以前から閉塞型睡眠時無呼吸低呼吸 症候群を呈していたことが推察され，脳血管障害 発症の 1 つの要因となった可能性が示唆される。

失語症状の回復には利き手, 発症時の年齢, 初 期の失語症の重症度, 病因, 病巣の位置や大きさ,
適切で十分な訓練実施の有無など多要因が関与す るものの，本症例のように比較的若年の発症であ り, 後方限局損傷で, かつ, 大脳皮質の萎縮や脳 室拡大などのびまん性病変が明らかでない場合， かなりの回復が期待できることもわかってきてい る（佐野ら 1992，1996，2000，中川ら 2002）。

その機能回復の機序についての研究報告は次の 3 つに大別される。すなわち，(1)損傷部位（右利 き症例であれば左半球）周辺の部分的機能回復や 機能再構築とする研究報告 (Rosen 5 2000), (2) 損傷されたのとは反対の大脳半球 (右半球) 側に おける言語野の対象部位の機能活性化によるとす る研究報告 (Thulborn ら 1999), (3)両側半球の関 与を示唆する研究報告である。とくに(3)関して は次に述べるような注目すべき研究報告が蓄積さ れつつある。Mimura ら（1998）, 三村（2000）は, 失語症の経過と SPECT の所見との関係を検討し, 発症初期には損傷部位と同側の半球内が，長期経 過後は対側の半球が機能回復に関与することを示 唆し, 回復良好例と不良例では脳の血流量に差異 があるとも述べている。このことは失語症の回復 には, 同側であれ対側であれ, 残存脳の機能の状 態がよいことが重要であることを示唆している。 またfMRIを用いた Goldら（2000）の研究，PET と fMRI を用いた Kuestら（2002）の研究でも，個 人差はあるものの，脳卒中後の失語症の回復には 両側大脳半球にあるネットワークの修復が関与す ることを示唆している。

一方，中等度の OSAHS では SPECT 所見におい て，同年齢の非 OSAHS 群に比べて脳血流の低下 を認め, $\mathrm{nCPAP}$ 導入後約 1 力月で脳血流が増加す ることが報告されている（小野 2000）。また，ラ ットを用いた睡眠時無呼吸症モデル実験において， 睡眠中繰り返し低酸素に曝露させると, 空間認知 能力が低下し, 海馬領域のアポトーシスが存在す ることが報告されている（Gozalら 2001）。これは OSAHS における学習や記憶障害に関連する可能性 を示唆する報告として非常に興味深い。本症例は 2 年間集中的言語訓練を実施したにもかかわらず 言語機能は回復に困難を示したが，本格的 nCPAP を導入して 2 力後ぐらいから短期間に急速に言 語機能は大きく変化した。このことは OSAHSに 
よる低酸素血症が言語機能訓練を膠着状態に陥れ た可能性，および nCPAP 開始後の脳血流や低酸素 血症の改善が残存脳の機能改善をもたらし,これ により短期間に大幅に言語機能が回復した可能性 を強く示唆するものである。

本症例では, 2002 年 2 月以降も, 検査所見上お よびコミュニケーション行動上, 緩やかではある が発話と意味理解の面で回復が続いていること, 途中で事情により nCPAPを用いなかった時に発話 能力に低下がみられたことなども，本症例の失語 症の回復に OSAHSへの治療が寄与していること を示唆していると考えて, 間違いないであろう。 OSAHS の積極的治療が低酸素血症や脳血流の改 善をもたらし，言語機能回復を促進したと考えら れる本症例の経過は, 長期的な失語症の機能回復 には残存脳の機能の良否がかかわる可能性を示唆 した先行研究の知見を支持するものと言えよう。

失語症の機能回復に対しては, 妥当なしかも十 分な期間の言語訓練が必要なことは言をまたない が, 残存脳の状態をよくする工夫は重要な治療手 法として今後検討されるべきものと考えられる。

\section{結語}

(1) 閉塞型睡眠時無呼吸低呼吸症候群（OSAHS） を合併する, 43 歳発症の重度失語症者に, nCPAP を導入したところ，2 年あまりの言語訓練におい ても回復に困難を示していた呼称や漢字の音読な どの課題で，短期間に大きな改善を示したので経 過を報告した。

（2）OSAHS を合併する失語症例に対しては, OSAHS への積極的な治療が，言語機能回復に対し て有用である可能性が示唆された。

(3) 本症例の経過は, 長期的な失語症の回復の 良否には対側も含めた残存脳の状態が関与すると する近年の知見を支持するものである。

\section{文 献}

1 ) Bassetti, C., Aldrich, M. S., Chervin, R. D., et al. : Sleep apnea in patients with transient ischemic attack and stroke. A prospective study of 59 patients. Neurology, 47 : 1167-1173, 1996.
2 ) Dyken, M. E., Somers, V. K., Yamada, T., et al. : Investi-gating the relationship between stroke and obstructive sleep apnea. Stroke, 27 : 401-407, 1996.

3 ) Gold, B.T. \& Kertesz, A. : Right hemisphere semantic processing of visual words in an aphasic pati-ent : An fMRI study. Brain Lang., 73 : 456-465, 2000.

4 ) Gozal, D., Daniel, J. M. \& Dohanich, G. P. : Behavioral and anatomical correlates of chronic episodic hypoxia during sleep in the rat. J. Neurosci., 21 : 2442-2450, 2001.

5 ) Koskenvuo, M., Kaprio, J., Partinen, M., et al. : Snoring as a risk factor for hypertension and angina pectoris. Lancet, 1 : 893-896, 1985.

6 ) Koskenvuo, M., Kaprio, J., Heikkila, K., et al. : Snoring as a risk factor for ischemic heart diseases and stroke in men. Br. Med. J., 294 : 16-19, 1987.

7 ) Kuest, J. \& Karbe, H. : Cortical activation studies in aphasia. Curr. Neurosci. Rep., 2 : 511-515, 2002.

8 ) Mimura, M., Kato, M., Kato, M., et al. : Prospective and retrospective studies of recovery in aphasia, changes in cerebral blood flow and language functions. Brain, 121 : 2083-2094, 1998.

9 ) 三村 將: 失語症の回復過程における左右大脳 半球の役割一SPECTを用いた検討一, 音声言語 医学, $42: 166-174,2000$.

10）中川良尚, 佐野洋子, 小嶋知幸, ほか：流暢型 失語症の長期経過一画像所見とSLTA成績からの 検討一 (会). 失語症研究, $22 ： 63,2002$.

11）小野容明：睡眠時無呼吸症候群と生活習慣病, 生活習慣病に打ける睡眠呼吸循環障害の重要性 の再認識. 生活習慣病と睡眠呼吸循環障害の因 果関係 4 脳循環障害. Mebio, 17 : 69-74, 2000.

12) Partinen, M. \& Palomaki, H. : Snoring and cerebral infraction. Lancet, 2 : 1325-1326, 1985.

13) Rosen, H. J., Petersen, S.E., Linenweber, M.R., et 
al. : Neural correlates of recovery from aphasia after damage to left inferior frontal cortex. Neurology, 55 : 1883-1894, 2000.

14）佐野洋子, 宇野 彰, 加藤正弘：SLTA成績に見 る失語症状の長期経過. 失語症研究, $12 ： 23-$ 36, 1992.

15）佐野洋子, 加藤正弘, 小嶋知幸 : 失語症状の長 期経過. 失語症研究, $16 ： 123-133,1996$.

16）佐野洋子, 小嶋知幸, 加藤正弘：失語症状の病 巣別回復経過の検討。失語症研究, $20: 311-318$,
2000.

17) Thulborn, K.R., Carpenter, P. \& Just, M.A. : Plasti - city of language-related brain functioning recovery from stroke. Stroke, 30 : 749-754, 1999.

\section{Abstract}

\section{Effects of nasal continuous positive airway pressure on recovery from aphasia}

\section{Eiki Ito* Yoko Sano** Tomoyuki Kozima** Yasuhisa Shinkai $^{* * * *}$ Masahiro Kato ${ }^{* * * *}$}

We experienced a case of aphasia whose language abilities showed good recovery after introduction of nasal continuous positive airway pressure (nCPAP) for treatment of obstructive sleep apnea hypopnea syndrome (OSAHS) . The subject was a 43-year-old right-handed male university graduate. He developed a cerebral hemorrhage after a shunt operation for cerebral vein sinus thrombosis in March 1999, and right hemiplegia and severe aphasia remained. He was admitted to Edogawa Hospital eight months after the onset, and started undergoing intensive therapy for aphasia. He experienced sleep apnea and snoring before the onset, and was diagnosed by polysomnography as having moderate OSAHS. After two years of language training for aphasia, we introduced nCPAP to the subject. The standard language test of aphasia (SLTA) revealed remarkable improvement, especially in the subtests of speech that had showed slow recovery, compared with performances before the introduction of nCPAP. In addition, fluency of conversation in daily life also improved, resulting in much easier communication. These results suggest that ventilation with nCPAP is effective for recovery from aphasia.

\footnotetext{
* Department of Respiratory Medicine, Shizuoka Medical Center. 762-1 Nagasawa, Shimizu-cho, Sunto-gun, Shizuoka 411-8611, Japan

*** Department of Rehabilitation,Edogawa Hospital

*** Department of Neurology, Edogawa Hospital
} 